\title{
FIGHTING CORRUPTION THROUGH REGIONAL AND INTERNATIONAL CONVENTIONS: A SATISFACTORY SOLUTION?
}

\section{INDIRA CARR*}

\begin{abstract}
While considering the current legal frameworks adopted by the regional and international anti-corruption conventions this article aims to show (1) that the lack of a unified approach is unlikely to further the fight against corruption in any meaningful way, (2) that regulation is unlikely to be efficient results unless there are robust enforcement mechanisms in place, and (3) that anti-corruption legislation provides only a partial answer and that we need to engage in what I call a process of re-socialization. Part 2 (How Widespread is Corruption?) critically assesses the methodology adopted by Transparency International (TI) for compiling its perception index. Part 3 (Regulatory Measures: The Conventions) examines the current frameworks adopted by the existing conventions to tackle corruption. Part 4 (Enforcement and Informers) highlights the difficulties associated in enforcing the conventions and explores whether the antiquated qui tam action might serve a useful purpose in addressing enforcement deficit. Part 5 (Fighting Corruption Through Re-Socialization) asks whether greater social awareness through education provides a possible solution. Guided by a humanistic philosophy of society the view is put forward that part of the answer for effectively tackling corruption lies in making people aware of its long-term effects.
\end{abstract}

\footnotetext{
* Professor of Law, Centre for Legal Research, Middlesex University; Honorary Visiting Professor, University of Exeter; Visiting Scholar, BRASS, Cardiff University. I would like to thank BRASS (the ESRC Centre for Business Relationships, Accountability, Sustainability \& Society) at Cardiff University for their hospitality during July 2006 when much of this article was written.
} 


\section{Introduction}

Since the mid-1990s world attention ${ }^{1}$ has been drawn to the problem of corruption and much has been said and written about the links between corruption and poverty. ${ }^{2}$ As a result regional and international institutions have been hyperactive in drafting and adopting legislation to combat corruption. We now have eight regional and international conventions. Not all are in force. ${ }^{3}$ While it would be logical to expect that these conventions have adopted a harmonized approach to combating corruption, the scope of these legal instruments vary and conventions drafted more recently have taken an increasing robustness in their comprehensiveness by creating offences that may be arguably questioned for their disregard of due process. ${ }^{4}$

This article examines the current legal frameworks adopted by the conventions, regional and international, with the aim of showing (1) that the lack of a unified approach is unlikely to further the fight against corruption in any meaningful way, (2) that regulation is unlikely to be efficient results unless there are robust enforcement

\footnotetext{
${ }^{1}$ Civil society organisations, Transparency International (TI) amongst them, have done much to draw world-wide attention to this menace. Since the mid 1990s, TI has been publicising the incidence of corruption in countries through its now well established, and widely known and cited corruption index. The list of countries in their index has increased steadily and includes countries, developed and developing. These statistics are published by TI on an annual basis. The corruption indices from 1995 onwards are available on their website http://www.transparency.org

${ }^{2}$ See Alatas, S Corruption, Its Nature, Causes and Functions (1990) Aldershot: Brookfield, Bergstein \& Elliott K (eds) Corruption in the World Economy 1997 Washington: Institute for International Economics; Mbaku 'Africa after More than Thirty Years of Independence: Still Poor and Deprived" 1994 (11) Journal of Third World Studies 13, Askin, S \& Collins, C 'External Collusion with Kleptocracy: Can Zaire Recapture its Stolen Wealth?' 1993 (53) Review of African Political Economy, Gould D \& Mukendi 'Bureaucratic Corruption in Africa: Causes, Consequences and Remedies' 1989 (12) International Journal of Public Administration 427; Guhan S \& Paul S (eds) Corruption in India: An Agenda for Action (1997) New Delhi: Vision Books; Eliminating World Poverty: Making Globalisation Work for the Poor Cmnd 5006 (2000) London: HMSO; Rose-Ackermann S ‘The Economics of Corruption’ (1975) 4 Journal of Public Economics 187; Dudley 'The Rotten Mango: The Effect of Corruption on International Development Project' available at http://www.user.gwdg.de , Lambsdorff 'How Corruption affects Public Welfare' (2001) Discussion Paper 9, Center for Globalisation and Europeanisation, University of Goettingen. Gray, C W \& Kaufmann, D 'Corruption and Development' in 1998 (35) Finance and Development 7, Tanzi, V 'Corruption around the World: Causes, Consequences, Scope and Cures' 1998 (45) IMF Staff Papers 559Corruption may also have something positive to contribute. For instance, in a highly bureaucratic state corruption may speed up the mechanism for economic development. On the positive aspects of corruption see Heidenheimer, Johnston M \& Le Vine V (Eds) Political Corruption: A Handbook (1989) London: Transaction Publishers.

3 See 'Regulatory Measures' below.

4 See Carr I 'Corruption in Africa - Is the African Union Convention on Combating Corruption the Answer?' forthcoming Journal of Business Law.
} 
mechanisms in place, and (3) that anti-corruption legislation provides only a partial answer and that we need to engage in what I call a process of re-socialization. Part 2 (How Widespread is Corruption?) critically assesses the methodology adopted by Transparency International (TI) for compiling its perception index. Part 3 (Regulatory Measures: The Conventions) examines the current frameworks adopted by the existing conventions to tackle corruption. Part 4 (Enforcement and Informers) highlights the difficulties associated in enforcing the conventions and explores whether the antiquated qui tam action might serve a useful purpose in addressing enforcement deficit. Part 5 (Fighting Corruption Through Re-Socialization) asks whether greater social awareness through education provides a possible solution. Guided by a humanistic philosophy of society I put forward the view that part of the answer in tackling corruption lies in making people aware of its long-term effects.

Before proceeding with the task at hand I wish to dispel some commonly held beliefs in respect of corruption. It must not be surmised from the close relationship between corruption and poverty that it is exclusively a developing country problem. It occurs in developed countries, ${ }^{5}$ the recent scandal in Britain surrounding the Labour Party peerages for loans ${ }^{6}$ being one possible such illustration. Recently, the TI has also published a bribery index which shows that many of the commercial interests from developed countries are engaged in bribing public officials in developing countries. ${ }^{7}$ These cases of bribery occur in the context of public procurement contracts, licensing and foreign direct investment ${ }^{8}$ thus reinforcing the opinion of policymakers and think tanks

\footnotetext{
${ }^{5}$ Doig, A Corruption and Misconduct in Contemporary British Politics (1984) Harmondsworth: Penguin. 6 See The Independent May 17, 2006, The Daily Telegraph July 16, 2006.

7 There is also evidence of this from the various prosecutions in countries such as the US that companies through their employees or agents engage in the bribing of foreign public officials. See e.g. SEC v Triton Energy Corp Fed Sec 1 Rep (CCH) P 74, 405 (DDC Feb 27, 1997); ICC Case no 6401 (199.1991) Westinghouse and Burns \& Roe (USA) v National Power Company and the Republic of the Philippines; see also Scherer, M 'Circumstantial Evidence in Corruption Cases Before Arbitral Tribunals' 2002 (5:2) International Arbitration Law Review 29; Kimberly A E (ed) Corruption and the Global Economy (1997) Washington DC, The Institute for International Economics; Wei S J How Taxing is Corruption on International Investors NBER Working Paper 6030 (1997) National Bureau of Economic Research; Wei S $\mathrm{J}$ Corruption in Economic Development: Beneficial Grease, Minor Annoyance or Major Obstacle? Policy Research Working Paper 2048 (1999) Washington DC: The World Bank.

8 See Hartman, M 'Government by Thieves: Revealing the Monsters behind the Kleptocratic Masks' 1997 (24) Syracuse Journal of International law and Commerce 157; Jun D J 'Bribery among the Korean Elite: Putting an End to a Cultural Ritual and Restoring Honor' 1996 (29) Vanderbilt Journal of Transnational Law 1071; Lajcakova, J 'Violation of Human Rights through State Tolerance of Street-Level Bribery: Case Study: Slovakia' 2003 (9) Buffalo Human Rights Law Review 111; Ferreiro, A 'Corruption, Transparency
} 
from developing countries that developed countries are equally to blame for their contribution to grand corruption in their countries. ${ }^{9}$ Evidence also indicates that affluent developed countries are equally prone to corruption at the petty level as the recent scandal surrounding possible corruption amongst prison personnel ${ }^{10}$ suggests.

Neither is corruption a by-product of ruthless capitalism, which promotes selfinterest and maximum economic growth as opposed to the interests of the community. While it is true that in a competitive global market, where countries such as China and India offer lucrative returns as a result of cheap labour and lax environmental and labour standards, bribes play a role in getting a foothold, it is by no means a product of capitalism. Corruption was found equally in the bureaucracies of non-capitalist countries such as the USSR. ${ }^{11}$ It seems to be a universal disease found in all societies regardless of the political, social, religious and economic background.

In addressing corruption, the importance of the motivations and reasons for corrupt behaviour cannot be overstated. An understanding of the underlying reasons will help towards the creation and adoption of a suitable remedial strategy that might require a conscious, energetic and persistent effort in imparting information at the ground level about the detrimental effects of corruption thus empowering citizens to adopt suitable measures to curb corruption. A noticeable aspect of many of the studies on corruption is that they fail to take into account human nature which has as much to contribute to corruption as socio-economic conditions.

\section{How Widespread is Corruption?}

and Political Financing: Some Reflections on the Experience in Chile' 2004 (10) Southwestern Journal of Law and Trade in the Americas 345.

${ }^{9}$ The belief that the private sector is also to be blamed for corruption is also acknowledged by the Center for International Private Enterprise, an affiliate of the US Chamber of Commerce. According to them "NGOs and civil society organisations alone can't reduce corruption - business participation is the key to success. The stakes for the business sector are high - if businesses chose to remain on the sidelines and continue to participate in corruption they face missing opportunities for foreign investment." Center for International Private Enterprise Economic Reform Issue Paper No 0409 September 22, 2004. Available at http://www.cipe.org .

${ }^{10}$ See 'Main Jail Staff Corrupt - Report' July 31, 2006 available http://news.bbc.co.uk. 11 See Simis, K USSR: The Corrupt Society (1982) New York: Simon Schuster. Russia continues to be a highly corrupt society and President Putin has launched a high profile anti-corruption drive which has seen the removal of a number of high level officials in departments such as customs, internal affairs ministry and federal security services. See 2006 (58:20) The Current Digest of the Post-Soviet Press 1. 
Anecdotal evidence from businessmen and tales of morally questionable behaviour on the part of public servants by visitors to and from third world countries normally go a long way in forming the impression that corruption is a highly visible phenomenon in many of the developing and least developed countries. Indeed in some countries it is said to be systemic and so embedded culturally that to try to root out corruption is seen as an impossible task. To conclude from such anecdotal evidence that corruption is common place in developing countries is methodologically suspect since it lacks objectivity. A better alternative may be to examine a country's crime statistics, number of complaints and prosecutions ${ }^{12}$ for corruption and corruption related offences. This method also has its flaws. It is reliant on a number of assumptions. Among these:

- that there is a culture of complaint/disclosure of fraud,

- that there is legislation criminalising various forms of corrupt behaviour such as bribes and trading in influence,

- that corruption and corruption related offences are listed separately ${ }^{13}$ and not subsumed under other offences such as fraud, embezzlement or extortion,

- that there is an effective investigation and prosecutorial system that is trusted by the citizens,

- that there is easy access to justice,

- that the country maintains an efficient database of complaints, prosecutions and convictions, and

- that the statistics are reliable and publicly available.

Unfortunately, many countries do not have corruption specific legislation though this is changing due to the work of the Organisation for Economic Co-operation and Development (OECD), the United Nations (UN) and other regional institutions such as the African Union (AU) and the South African Development Community (SADC).

12 According to Lambsdorff "the number of prosecutions reflects only the quality of the prosecutors". (The Methodology of the 2005 Corruption Perceptions Index available at http://www.transparency.org ) 'Quality' is a value laden term and it is unclear whether for instance it refers to the truth seeking aspects and thoroughness of the prosecutors or whether it refers to a willingness to prosecute readily any allegation of corruption. I do however agree that prosecution of itself is insufficient to gauge the actual levels of corruption in a country since many cases of corruption may not reach the prosecution stage.

13 The Indian National Crime Records Bureau records cases under the Prevention of Corruption Act separately. Figures available at http://www.ncrb.nic.in . 
Equally crime statistics are gathered (sometimes sporadically) ${ }^{14}$ by home affairs directorates and police commissions but these are not made publicly available thus making it difficult to assess the true extent of the problem. In some countries underreporting is acute due to lack of trust in the police. This is true of many of the developing countries. ${ }^{15}$

Even if a jurisdiction meets the criteria listed above prosecution figures may only convey part of the story since many instances of corrupt behaviour may not be prosecuted due to lack of evidence or may go unreported for a number of reasons such as:

- fear of reprisals from the recipient of the bribe,

- apathy,

- ignorance of legal rights,

- lack of access to justice,

- lack of trust in the police,

- lack of transparency in the judicial system, and

- fear of involvement in a long drawn out process.

Facts and figures while imparting objectivity at present provides only a partial picture and it would be illogical to conclude from these that corruption is an endemic problem globally. This inevitably raises some interesting questions in respect of the TI index on which we have come to place so much reliance. Among the questions are those in respect of methodology and reliability.

Based on perceptions, the TI draws upon a number of sources, private, nongovernmental organisations and international institutions. Their selection is guided by various criteria that seems to seek some level of uniformity of methodology amongst the sources selected. Whether the sources provide a ranking of countries, and whether they measure the overall extent of corruption without mixing it with issues such as political instability are some of the criteria that influence the choice of sources. ${ }^{16}$ For the 2005

14 For instance, Lesotho, Namibia and Malawi.

15 See Strategic Programme Framework on Crime and Drugs for Southern Africa (2003) Vienna: United Nations Office on Drugs and Crime; Crime and Development in Africa (2005) Vienna: United Nations Office on Drugs and Crime.

16 See Lambsdorff The Methodology of the 2005 Corruption Perceptions Index. The TI Steering Committee influences the choices. 
index the TI drew data from surveys produced by the Center for International Earth Science Information Network (CIESIN), ${ }^{17}$ the Economic Intelligence Unit (EIU), ${ }^{18}$ Freedom House Nations in Transit (FH), ${ }^{19}$ Information International (II), ${ }^{20}$ International Institute for Management Development (IMD), ${ }^{21}$ Merchant International Group (MIG), ${ }^{22}$ Political and Economic Risk Consultancy, (PERC), ${ }^{23}$ United Nations Economic Commission for Africa (UNECA), ${ }^{24}$ the World Economic Forum (WEF), ${ }^{25}$ and the World Markets Research Centre (WMRC). ${ }^{26}$ It must however be pointed out that the level of uniformity achieved through the selection criteria is not influenced by aspects of the data gathering process. There are noticeable variations between the sources in terms of those surveyed, the number of countries covered and the questions asked. Taking the constituency used for the purposes of conducting the surveys, the IMD relies on businesspeople, UNECA on a local expert panel, PERC on expatriate business executives while CIESIN relies on US-resident country experts drawn from policy analysts, academics and journalists. The number of countries covered as well as the number of responses vary from source to source. For instance, CIESIN covered 95 countries and received 224 replies, IMD 51 countries with roughly 4,000 replies while WEF covered 117 countries and received 10,993 replies from a constituency consisting of senior business leaders of domestic and international companies. As to the nature of the questions broached in the survey there is wide variation again. While the subject matter under consideration is corruption in broad terms the questions vary in terms of specificity. For instance, the II focuses on the economic costs of corrupt behaviour including the issue of nepotism in the context of public contracts, IMD on bribery and corruption in the economy, and $\mathrm{FH}^{27}$ on the extent of corruption as practiced in

$17 \mathrm{http}: / /$ www.ciesin.org .

$18 \mathrm{http}: / /$ www.eiu.com .

$19 \mathrm{http}: / / \mathrm{www}$.freedomhouse.org .

$20 \mathrm{http}: / / \mathrm{www}$. information-international.com .

$21 \mathrm{http}: / / \mathrm{www} . \mathrm{imd} . \mathrm{ch}$.

$22 \mathrm{http}: / /$ www.merchantinternational.com .

$23 \mathrm{http}: / /$ www.asiarisk.com.

$24 \mathrm{http}: / /$ www.uneca.org.

$25 \mathrm{http}: / / \mathrm{www}$.weforum.org.

$26 \mathrm{http}: / / \mathrm{www}$. globalinsight.com.

27 The country reports (Nations in Transit) are in essay format where the authors provide a broad analysis of the country of their expertise. However FH provides a checklist of questions on seven categories which includes corruption. They also provide guidelines for ratings. 
governments as perceived by the public and as reported in the media, laws on financial disclosure and conflict of interest as well as the implementation of anticorruption initiatives. While the TI has made every effort to ensure some sort of parity in methodology by taking into account the use of a ranking system and subject focus in the selection criteria of the sources used for the corruption index there is wild deviation between the sources in terms of detail. Survey questions vary, some focusing solely on corruption in the public sector. They utilise people from different backgrounds to arrive at their data, some rely on the business sector while others on country experts. Regardless of the concerns about lack of a uniform approach in data collection what TI has highlighted is that corruption is perceived as a global problem, be it in a business or in a wider context. While the TI does not provide us with a knowledge of true reality it nevertheless provides a shadowy representation sufficiently convincing to influence a multitude of international and regional institutions to draft corruption specific instruments with the result that the fight against corruption has been internationalised. The growth in the number of international initiatives is an indicator of the high profile given to corruption by policymakers and politicians. Regardless of the impact of TI on national and international law-making there is still the pressing issue of whether the methodology of arriving at corruption levels could be made more robust in providing knowledge of the true extent of the problem. What has to be realised is that corruption is a secretive activity and as such we are reliant on reflections. All that we can do is to sharpen these reflections. This may be achievable by increasing the survey sample and ensuring greater homogeneity in the constituency and harmonisation of the survey questions.

\section{Regulatory Measures: The Conventions}


Regulation, ${ }^{28}$ using a variegated mix of cautions, fines, loss of freedom, and incentives, is a popular choice amongst policy makers and politicians as a means of achieving the desired goal. It exploits the psychological aspects of human beings. Fear of loss of freedom and social stigma attached to criminal records, for instance are all seen as sufficiently effective to deter ${ }^{29}$ undesirable behaviour and mould the social condition of mankind to a preconceived standard. Given the human propensity towards a degree of unpredictability and an inclination towards rule ignoring, sanctions play an important role in guiding human choice. Their negative impact on a person's identity and status both in the short and long term may 'persuade' the person to reconsider their motivations and desires. Sanctions, however, do not serve the moulding of human behaviour as well one would expect as made apparent by crime statistics. In these circumstances we have to ask whether there are alternatives to regulation that might work better, an issue that will be explored in Part 5 below.

To tackle the global problem of corruption international institutions and regional groupings look to criminal law as a means of regulating human behaviour. Since 1996, eight conventions have been adopted for combating corruption. Of these, seven ${ }^{30}$ see criminal law as the vehicle for combating corruption. Given the number of international and regional institutions involved in drafting corruption combating legislative frameworks for adoption by Contracting States it would be reasonable to expect that there has been mutual co-operation between the various regional bodies and international institutions resulting in a largely harmonised and a comparatively uniform legislative approach to fighting corruption amongst the Contracting States. Unfortunately the

\footnotetext{
${ }^{28}$ Use of regulation as a means of solving various social problems has been on the increase world wide. Whenever there is a perceived social problem the answer for legislators seems to lie in legislation. The UK is no stranger to this approach. (See Hall S Drifting into a Law and Order Society 1980 London: Cobden Trust Williams P \& Dickensen J 'Fear of Crime' 1993 British Journal of Criminology 33.) The recent introduction of Anti-Social Behaviour Order (ASBO) in the UK to tackle socially disruptive behaviour of largely teenagers and young adults is one such illustration. There is always the danger that such regulation may be used as part of a public relations exercise by the government of the day to indicate to the public that it is taking its paternalistic role seriously. With a twist of cynicism it may also be seen as intricately linked to electoral results.

${ }^{29}$ According to Vogelson J M it seems that the US Foreign Corrupt Practices Act has deterred the corrupt practices of US firms. See 'Report of the ABA Committee on Corrupt Practices to the ABA' 1996 (30) International Lawyer 194. 30 Council of Europe Civil Law Convention on Corruption 1999 deals with civil actions for those who have suffered damage as a result of acts of corruption. It came into force on I November 2003 and has received 27 ratifications or accessions. See Carr, I 'Civil Law and Corruption' (forthcoming).
} 
conventions vary in terms of both substantive and procedural provisions, and comprehensiveness. Lack of conformity between the conventions means that the Contracting States are likely to tackle the issue of corruption in different ways thus leaving the door wide open to uncertainties, extradition in the context of transnational corruption being one of these.

It is not the intention here to examine the provisions of each convention in great detail. The aim here is to amplify the differences and points of departure by focusing on specific topics: corruption and corruption-related offences; preventive measures; mutual assistance and international co-operation with the intention of highlighting the lack of coherence in the current international legal frameworks. The conventions that are considered for this purpose are chronologically:

i) Organisation of American States Inter-American Convention Against Corruption 1996 (hereinafter "OAS Convention); ${ }^{31}$

ii) Organisation for Economic Co-operation and Development Convention on Combating Bribery of Foreign Public Officials in International Business Transactions 1997 (hereinafter "OECD Convention") 32

iii) Convention drawn up on the basis of Article K.3 (2) (c) of the Treaty on European Union on the Fight Against Corruption involving Officials of the European Union Communities or Officials of Member States of the European Union 1999 (hereinafter "EU Convention") 33

\footnotetext{
${ }^{31}$ Came into force on 6 March 1997 and the following countries have ratified or acceded to it: Argentina, Antigua \& Barbuda, Bahamas (Commonwealth), Belize, Bolivia, Brazil, Canada, Chile, Colombia, Costa Rica, Dominica, Dominican Republic, Ecuador, El Salvador, Grenada, Guatemala, Guyana, Haiti, Honduras, Jamaica, Mexico, Nicaragua, Panama, Paraguay, Peru, St Kitts \& Nevis, St Lucia, St Vincent \& Grenadines, Trinidad \& Tobago, United States, Uruguay, and Venezuela.

${ }^{32}$ Came into force on 15 February 1999 and has received ratifications or accessions from Argentina, Australia, Austria, Belgium, Brazil, Bulgaria, Canada, Chile, Czech Republic, Denmark, Estonia, Finland, France, Germany, Greece, Hungary, Iceland, Ireland, Italy, Japan, Korea, Luxembourg, Mexico, Netherlands, New Zealand, Norway, Poland, Portugal, Slovak Republic, Slovenia, Spain, Sweden, Switzerland, Turkey, United Kingdom and the United States.

${ }^{33}$ Still in the process of receiving ratifications. See also Council Framework Decision 2003.568/JHA of 22 July 2003 on combating corruption in the private sector (OJ L 192 of 31.07.2003). According to Art 249 of the EC Treaty as amended by the Treaty of Amsterdam a decision is binding in its entirety upon those to whom it is addressed.
} 
iv) Council of Europe Criminal Law Convention on Corruption 1999 (hereinafter "COE Convention) ${ }^{34}$

v) Southern African Development Protocol Against Corruption 2001 (Hereinafter "SADC Protocol") ${ }^{35}$

vi) African Union Convention of Preventing and Combating Corruption 2003 (hereinafter "AU Convention); ${ }^{36}$

vii) United Nations Convention Against Corruption 2003 (hereinafter "UN Convention"); ${ }^{37}$

viii) Council of Europe Additional Protocol to the Criminal law Convention on Corruption 2003 (hereinafter "COE Protocol") ${ }^{38}$

\section{A. Corruption - The Scope}

The starting place for any convention is its scope. It would be normal to expect the conventions to define the word 'corruption'. Admittedly corruption is a fairly complex concept due to its multi-dimensional character and the word is used in a variety of senses from moral degradation to the economic benefit obtained by an individual in a position of

\footnotetext{
${ }^{34}$ Came into force on 1 July 2002 and has received ratifications from Albania, Armenia, Azerbaijan, Belgium, Bosnia and Herzegovina, Bulgaria, Croatia, Cyprus, Czech republic, Denmark, Estonia, Finland, Hungary, Iceland, Ireland, Latvia, Lithuania, Luxembourg, Malta, Moldova, Netherlands, Norway, Poland, Portugal, Romania, Russia, Serbia, Slovakia, Slovenia, Sweden, Switzerland, the former Yugoslav Republic of Macedonia, Turkey, and United Kingdom.

${ }^{35}$ Not yet in force. So far the following have ratified : Botswana, Lesotho, Malawi, Mauritius, South Africa, Tanzania, Zambia, and Zimbabwe.

${ }^{36}$ Came into force on 5 August 2006. It has been ratified by Algeria, Burkina Faso, Burundi, Comoros, Congo Libya, Lesotho, Madagascar, Mali, Namibia, Niger, Rwanda, South Africa, Tanzania and Uganda.

${ }^{37}$ Came into force on 14 December 2005. So far the following ratifications or accessions have taken place: Albania, Algeria, Angola, Antigua \& Barbuda, Argentina, Australia, Austria, Azerbaijan, Belarus, Benin, Bolivia, Brazil, Bulgaria, Burkina Faso, Burundi, Cameroon, Central African Republic, Chile, China, Congo, Croatia, Djibouti, Ecuador, Egypt, El Salvador, Finland, France, Honduras, Hungary, Indonesia, Jordan, Kenya, Kyrgyzstan, Latvia, Lesotho, Liberia, Libyan Arab Jamahiriya, Madagascar, Mauritius, Mexico, Mongolia, Namibia, Nicaragua, Nigeria, Norway, Panama, Paraguay, Peru, Poland, Romania, Russian Federation, Rwanda, Sao tome and Principe, Senegal, Serbia and Montenegro, Seychelles, Sierra Leone, Slovakia, South Africa, Spain, Sri Lanka, Tajikistan, Togo, Trinidad and Tobago, Turkmenistan, Uganda, United Arab Emirates, United Kingdom of Great Britain and Northern Ireland, United Republic of Tanzania, and Yemen.

${ }^{38}$ Came into force on 1 February 2005 and ratifications were received from Albania, Armenia, Bulgaria, Croatia, Denmark, Ireland, Latvia, Luxembourg, Netherlands, Norway, Romania, Slovakia, Slovenis, Sweden, Switzerland, the former Yugoslav Republic of Macedonia, and United Kingdom.
} 
power by virtue of that individual's role within an organisation. ${ }^{39}$ In practice, the conventions, other than the SADC Protocol, ${ }^{40}$ refrain from providing a general definition of corruption but focus on specific types of corrupt behaviour. It is however possible on the basis of the offences created by these conventions to group them into two conceptual frameworks. I call these 'Framework A' and 'Framework B' for convenience sake. Corruption, as stated earlier, can occur in different contexts but much of the corruption reported is in the context of public sector, be it at the petty or at the grand level. It is not uncommon to hear many anecdotes of petty corruption from those living in developing countries. The classic form of corruption, bribe, is a regular phenomenon in seeking the provision of basic services such as an electric or telephone connection from government owned utilities. At the grand level corruption veers its ugly head in a variety of situations ranging from public procurement contracts, the obtaining of licences and permits, foreign direct investment, construction contracts, through to tax incentives and arms deals. Framework A targets corruption in the public sector and addresses the issue of abuse/misuse of power by those in public office for private gain. ${ }^{41}$ Three of the conventions listed above, the OAS Convention, the OECD Convention, and the EU Convention concentrate solely on corruption of public officials though they vary in terms of scoping corrupt behaviour and defining public officials.

While corruption is much talked about in relation to government employees corruption is found also in the private sector. Wherever an individual is in a position of power and has opportunities to exercise discretion, be it directly or indirectly, in the decision making process opportunities for engaging in corrupt behaviour present themselves. Framework B conventions focus on the abuse/misuse of power in the decision making process for obtaining an undue advantage and are broader in scope than those Framework A conventions that relate to the public sector. Of course the types of

39 See Carr, I ‘Corruption in Africa: Is the African Union Convention the Answer?' forthcoming Journal of Business Law.

${ }^{40}$ Art 1 defines corruption as "any act referred to in Article 3 and includes bribery or any other behaviour in relation to persons entrusted with responsibilities in the public and private sectors which violates their duties as public officials, private employees, independent agents or other relationships of that kind and aimed at obtaining undue advantage of any kind for themselves or others". See 'Framework B' below for more on Art 3.

${ }^{41}$ The World Bank adopts this definition of corruption. See Ofusu-Amaah, W P , Soopramanien, R and Uprety, K Combating Corruption (1999) Washington DC: The World Bank. 
misuse, and the kinds of undue advantage outlawed vary between the conventions as the following paragraphs show.

\section{Framework A}

The OAS Convention is the earliest anti-corruption convention with the prime objective of eradicating corruption in the performance of public functions and has the following features:

- It creates corruption offences both in the context of mutual exchange between the offeror and the recipient and where there is no mutual exchange;

- It includes corrupt activities of both public officials and foreign public officials;

- It covers both passive bribery (solicitation and acceptance by a public official of a benefit in return for an act or omission) and active bribery (offering or granting of a benefit to a public official in return for the doing or not doing of act); and

- It creates a controversial offence of illicit enrichment.

The first corruption offence created by this convention is that of bribery. The solicitation or acceptance, or the offering or granting, directly or indirectly of any article of monetary value or other benefit in exchange for any act or omission in the performance of his public functions by a governmental official or public official is made an offence. ${ }^{42}$ The advantage gained by the public official can be for himself or another party and is not restricted to money but can include other advantages, a gift or a favour such as a holiday, a job, or a training contract for a third party. The term 'public official', construed to include government employees and those performing services in the name of the State, is sufficiently wide to include besides civil servants those working in public undertakings such as state trading corporations, various state agencies, and the judiciary. The OAS Convention has an extra-territorial dimension and makes active bribery of a foreign public official an offence. ${ }^{43}$ Foreign public official is not defined as such but presumably the definition of a public official referred to above will be relevant.

42 Arts VI(1)(a) \& (b). According to Art I 'public official', 'government official' or 'public servant' refers to any official or employee of the State or its agencies, including those who have been selected, appointed, or elected to perform activities or functions in the name of State or in the services of the State, at any level of its hierarchy. For further on this convention see Sutton R H 'Controlling Corruption through Collective Means: Advocating the Inter-American Convention Against Corruption' 1997 (20) Fordham International Law Journal 1427.

43 Art VIII. Note that the OECD Convention deals with corruption of a foreign public official in international business transactions. 
The OAS Convention, as stated earlier, addresses corrupt acts that do not involve a mutual exchange. Art VI includes acts or omissions by a public official for the purpose of illicitly obtaining benefits for himself or for a third party. This will cover acts such as failure to record donations and their diversion for personal or third party use. Since gains derived from corrupt behaviour are likely to be concealed the Convention also makes the use and concealment of property derived through corrupt acts as outlined in the Convention an offence. ${ }^{44}$

An interesting but questionable offence included in the OAS Convention is the offence of illicit enrichment. This is also found in a number of other conventions ${ }^{45}$ and has been a source of some debate. According to Art IX "each State Party that has not yet done so shall take the necessary measures to establish under its laws as an offense a significant increase in the assets of a government official that he cannot reasonably explain in relation to his lawful earnings during the performance of his functions. Among those States that have established illicit enrichment as an offense, such offense shall be considered an act of corruption for the purposes of this Convention". This article has been the source of some contention since it seems to place the burden on the accused to show that he has obtained his assets in a lawful manner. ${ }^{46}$ In some jurisdictions this may be seen as a necessary provision where there is total disregard of the law. Regardless, it goes against the grain of the expectation of a fair trial and right against self-incrimination enshrined in the various human rights treaties.

The next convention in chronological order which falls within Framework A is the OECD Convention. ${ }^{47}$ Unlike the OAS Convention the OECD deals only with transnational bribery and makes criminal active bribery of a foreign public official in the

\footnotetext{
$44 \operatorname{Art} \operatorname{VI}(1)(d)$.

${ }^{45}$ AU Convention and UN Convention.

46 See Gantz D A 'Globalising Sanction Against Foreign Bribery The Emergence of an International Legal Consensus' 1998 (18) North Western Journal of International Law and Business 457.

47 This was preceded by an Anti- bribery Recommendation 1994. For further on this see Buchan, D \& Graham, G 'OECD Members Agree Action to Curb Bribery of Foreign Official' Financial Times April 30, 1994. The OECD Convention is influenced by the US Foreign Corrupt Practices Act enacted in 1977 (hereinafter "FCPA"), when it became clear that multinationals such as Mobil and Lockheed were making payments to heads of states and senior civil servants for obtaining lucrative contracts. For further on this see Longobardi, L E 'Reviewing the Situation: What is to be Done with the Foreign Corrupt Practices Act?' 1987 Vanderbilt Journal of Transnational Law 431. In broad terms, the FCPA applies to persons (legal and natural) subject to US jurisdiction and makes payments intended to influence a foreign public official in the decision or decision making process an offence. There are also special provisions in respect of accounting procedures.
} 
context of international business transaction. This restricted ambit is not surprising given its historical antecedents in the US Foreign Corrupt Practices Act 1977. The OECD Convention focuses on the bribe giver and makes active bribery an offence. A promise given directly or indirectly, a pecuniary or other advantage to a public official in order to obtain or retain business or other improper advantage in the context of an international business transaction is an offence. There is no definition of international business transaction but its interpretation is likely to be guided by mercantile custom and international conventions ${ }^{48}$ and would presumably include transactions where parties to a business agreement are located in different jurisdictions.

The next instrument that restricts itself to the corrupt acts of public officials is the EU Convention. ${ }^{49}, 50$ This Convention addresses both active and passive corruption ${ }^{51}$ (namely, bribe offering and bribe soliciting) involving community and national officials. The meaning of national official is to be determined by reference to the definition of 'official' or 'public officer' in the national $\mathrm{law}^{52}$ of the Member State whereas the meaning of the "community official" ${ }^{53}$ is to be established by reference to the staff

48 International conventions relating to international sales such as the Vienna Convention on International Sales of Goods 1980 construe internationality in terms of the seller and buyer's place of business. See Art I(1).

49 There has been some reluctance among the Member States in respect of a EU wide criminal justice policy and this reluctance is understandable. For an interesting discussion on this aspect see Cloud, $\mathrm{M}$ 'Organized Crime, RICO and the European Union' 2000 (27) Syracuse Journal of International Law and Commerce 243. According to the TI corruption index among the EU 25 Greece, Italy, the Czech Republic and Poland have performed poorly compared to the other EU Member States and do not show any signs of improvement.

50 Text available OJ C 195, 1997, p2. See also Convention Drawn up on the Basis of the Article K3 of the Treaty of the European Union to the Convention on the Protection of the European Communities' Financial Interests (OJ C 313 1996, p2) and Protocol Drawn up on the Basis of Article K3 of the Treaty of the European Union to the Convention on the Protection of the European Communities Financial Interests (OJ V 11 1998, p,5). The Convention on financial interests came into force on October 17, 2002. Note that Art 20 of the EU Treaty lists the prevention and combating of corruption as one of the objectives of the creation of a European area of freedom, security and justice, The 1999 Tampere European Council identified corruption as a sector of particular relevance and the instruments that have resulted aim an approximating national legislation and the development of a general EU policy towards corruption. The European Parliament has also set its sight on corruption in developing countries and has recently published its 'Report on Aid Effectiveness and Corruption in Developing Counties' (RRl365027EN.doc of 27.2.2006) and adopted a European Parliament Resolution on Aid Effectiveness and Corruption in Developing Countries (2005/2141(INI)) on 6 April 2006.

${ }^{51}$ See Arts $2 \& 3$.

52 Art 1(c). Of course the meaning of 'public official' is likely to vary amongst the Member States. See Measures to Prevent Corruption in the Member States of the European Union, Working Paper of the European Parliament JURI 101 EN, Luxembourg 03-1998.

${ }^{53}$ Art 1(b) 
regulation of the European Communities and includes those seconded to the European Communities by the European States.

All of the above conventions are restrictive in scope in that they all focus on bribery with the exception of the OAS Convention which seems to reach farther into the recesses of human behaviour that could be classified as corrupt.

\section{Framework B}

The public sector in developing countries is often seen as the breeding ground for corruption. Since the public sector in these countries provides basic utilities with a huge consumer base many members of the public have experienced some level of bribery at the petty level. Some of the developing countries have therefore privatised ${ }^{54}$ or semiprivatised the utilities sector hoping that this would curb corruption. Since the private sector is profit seeking inevitably the charges of these utilities, once privatised, are high and puts them out of the reach of the low income group. This in its own way breeds corruption at the petty level, for instance, on the part of those taking meter readings for the purposes of billing by entering a lower meter reading or tampering with the mechanical parts of the meter to show a lower consumption in return for a payment.

Private sector corruption however is not restricted to the petty level. It is commonplace for senior managers to engage in corrupt activities in various contexts, for instance, in procurement and compromising confidential and sensitive company information. To root out corruption it is essential that the private sector is also included in the regulatory framework.

The earliest convention to include both the public and private sector is the COE Convention, focusing on the abuse of power in return for an undue advantage regardless of the context in which it occurs. In also takes a comprehensive approach in construing the term 'public official'. 55 The convention dispels doubts about which services are or

\footnotetext{
${ }^{54}$ Note also that privatisation is one the conditions imposed by the World Bank when providing loans to finance projects in developing countries. See Carr, I 'Corruption, the World Bank and Conditionalities' (forthcoming).

${ }^{55}$ Art 1(a) defines 'public official' as "shall be understood by reference to the definition of 'official', 'public officer', 'mayor', 'minister' or 'judge' in the national law of the State in which the person in question performs that function and as applied in its criminal law."
} 
are not included in the public sector by including specific provisions relating to active and passive bribery of domestic public officials, ${ }^{56}$ bribery of members of domestic public assemblies, ${ }^{57}$ foreign public assemblies, ${ }^{58}$ international parliamentary assemblies ${ }^{59}$ officials of international organisations, and judges and officials of international courts. ${ }^{60}$ The COE Protocol extends the list to include bribery of domestic and foreign arbitrators, and domestic and foreign jurors. ${ }^{61}$. However it fails in its comprehensiveness when it comes to the creation of offences. Corruption is construed within a narrow band that includes acts of active and passive bribery both at the domestic and international level ${ }^{62}$, and trade in influence over persons in the public sector such as domestic or foreign public officials, members of domestic and international parliamentary assemblies. The judiciary is separately addressed in Art 12. An accounting offence is also created to address fraudulent practices such as the creation or use of an invoice or other accounting document containing false or incomplete information, and unlawfully omitting to make a record of payment. ${ }^{63}$

A more comprehensive approach is adopted by the next three conventions in the chronological list : SADC Protocol, AU Convention and the UN Convention. The first two are regional conventions and likely therefore to have a limited impact unlike the UN Convention which is a truly international convention.

Turning our attention to the two African conventions, the SADC Protocol ${ }^{64}$ provides a definition in its Article 1 and focuses on the abuse of power in return for undue advantage. The specific acts of corruption condoned are listed in Art 3 and include active and passive bribery be it by a public official or a person working in the private sector, act or omission by a public official for illicitly obtaining benefits for himself or a third party, diversion by a public official of property, monies or securities of the State,

\footnotetext{
${ }^{56}$ See Arts 2 \& 3.

${ }^{57}$ Art 4.

${ }^{58}$ Art 6.

${ }^{59}$ Art 20.

${ }^{60}$ Art 11

61 Arts $2-6$.

${ }^{62}$ Arts 2-11.

${ }^{63}$ Art 14.

${ }^{64}$ The following countries are members of the SADC: Angola, Botswana, Democratic Republic of Congo, Lesotho, Malawi, Mauritius, Mozambique, Namibia, Seychelles, South Africa, Swaziland, Tanzania, Zambia and Zimbabwe. Most of these countries figure as highly corrupt in the TI index.
} 
individual or independent agency received by virtue of his position for his own benefit or that of a third party, the fraudulent use or concealment of property described from corrupt acts as listed in Art 3, and participation as principal, co-principal, agent, instigator, collaborator or accessory after the fact. The SADC Protocol also has a transnational aspect and includes the bribery of a foreign public official in its list of offences.

The AU Convention simply lists specific acts of corruption and related offences but in doing so is much wider in scope. It includes in its list passive and active bribery in the public and the private sector, the controversial provision on illicit enrichment, trading in influence, diversion of funds and concealment of funds resulting from acts of corruption. The classic example of corruption, bribery, is addressed in Art 4 and includes both the direct or indirect solicitation or acceptance by a public official ${ }^{65}$ or a person in the private sector of an undue advantage in exchange for an act or omission in the performance of his public function, or in breach of his duties. ${ }^{66}$ The AU Convention, like the OAS Convention, includes the controversial offence of illicit enrichment where a public official or any other person cannot reasonably explain the possession of those assets. ${ }^{67}$ The points made in respect of the offence of illicit enrichment in the OAS Convention equally apply here. Laundering or concealment of proceeds from corrupt activities is also made an offence. ${ }^{68}$ The AU Convention includes an interesting provision on the funding of political parties. It expects the Contracting States to proscribe the use of funds acquired through illegal and corrupt practices to finance political parties and incorporate the principle of transparency in such funding. ${ }^{69}$ This is a welcome provision since it is common practice in many developing countries to channel the proceeds of crime through the funding of political parties.

The AU Convention does not include bribery of a foreign public official within its list of corruption offences which is a surprise omission since a number of African businesses do engage in international investment, South Africa being one example.

\footnotetext{
65 Public official is defined in Art 1 as "any official or employee of the State or its agencies including those who have been selected, appointed or elected to perform activities or functions in the name of the State or in the service of the State at any level of its hierarchy." The definition is sufficiently wide to encompass all sectors including the judiciary and prosecuting authorities.

${ }^{66}$ Arts $4(1)(\mathrm{a})-(\mathrm{e})$.

${ }^{67}$ Arts $4(1)(\mathrm{g})$ and 8.

${ }^{68}$ Arts 4 and 6.

${ }^{69}$ Art 10.
} 
The UN Convention is the latest corruption related convention and it is expected to have a noticeable and successful international impact since it seems to have the support of international institutions such as the World Bank, the International Monetary Fund and policymakers from developing and developed countries. Indeed countries have made known their adherence to the UN Convention when passing legislation to combat corruption. ${ }^{70}$ It is much wider in scope than the previous two conventions in the group of three considered in this section. It criminalizes bribery of national officials, ${ }^{71}$ foreign public officials, ${ }^{72}$ officials of public international organisations, ${ }^{73}$ bribery in the private sector, ${ }^{74}$ embezzlement of property both in the public and private sector, ${ }^{75}$ trading in influence, ${ }^{76}$ illicit enrichment, ${ }^{77}$ abuse of function, ${ }^{78}$ and laundering and concealing the proceeds of corruption. ${ }^{79}$ In taking a comprehensive approach it also addresses aspects that may hinder enforcement and criminalises the use of physical force, threats or the offer of a bribe to induce false testimony or to interfere in the giving of testimony or production of evidence. Equally intimidation of officials in order to interfere with the exercise of their official duties in respect of the offences created by the Convention is made an offence. ${ }^{80}$

\section{B. Sanctions}

As with other international criminal conventions ${ }^{81}$ the approach towards sanctions is one of minimal interference or no interference in some cases. The SADC Protocol, the AU Convention and the OAS Convention subscribe to the latter approach in remaining silent in respect of penalties leaving it to the Contracting State to decide how to deal with offenders. It is indeed difficult to understand why the regional agreements have remained silent on this issue since members of regional organizations have normally come together

\footnotetext{
${ }^{70}$ See South African Prevention and Combating of Corrupt Activities Act 2004 No 12 of 2004.

${ }^{71}$ Art 15.

72 Art 16

73 Ibid.

$74 \frac{\text { Art } 21 .}{\text {. }}$

${ }^{75}$ Arts 17 and 22.

${ }^{76}$ Art 18.

${ }^{77}$ Art 20.

${ }^{78}$ Art 19.

${ }^{79}$ Arts 23 and 24.

${ }^{80}$ Art 25.

${ }^{81}$ E.g. Council of Europe Convention on Cyber-Crime 2003.
} 
to pursue common aims and may be expected to achieve these aims through the same means. The reason for the silence may be to avoid the rather sensitive and emotive issue of sovereignty given that a number of countries in these continents have troubling issues ranging from boundary disputes to political and civil unrest. To intervene in criminal justice matters could be seen as an encroachment of matters that should be left to the Contracting State to decide in keeping with its policy on criminal justice. The other conventions take a minimalist approach. The EU Convention, the OECD Convention, and the COE Convention in general terms expects the sanctions to be effective, proportionate and dissuasive and provides some indication of the range of sanctions that could be used for punishing corrupt conduct. This includes fines and loss of liberty. ${ }^{82}$ The UN Convention appears to sit somewhere in the middle though it can be said that it is perhaps more willing to cover other aspects of criminal justice since Art 41 for instance states that States may take "any previous conviction in another State for the purpose of using such information in criminal proceedings relating to an offence established in accordance with [the UN] Convention." While including a provision on sanctions it does not go as far as the European driven conventions in giving any indication of the forms the sanctions can take. In Art 30(1) it simply states that the gravity of the offence must be taken into account in determining the sanction but that loss of liberty is contemplated to be amongst the types of sanction is apparent from Art 30(5) which mentions early release and parole.

\section{Preventive Measures}

Prevention through the participation of citizens, those affected by corruption and closing the current loopholes in existing law such as banking law that may be used to deposit the proceeds of corruption are important means of fighting corruption. The UN Convention once again is expansive in its approach to prevention of corruption and deals with bank secrecy, ${ }^{83}$ prevention and detection of transfers of proceeds of crime, ${ }^{84}$ the creation of financial intelligence units, ${ }^{85}$ participation of society, ${ }^{86}$ improving accounting

\footnotetext{
${ }^{82}$ See Art 19 COE Convention, Art 3 OECD Convention, Art 5 EU Convention.

${ }^{83}$ Art 40.

${ }^{84}$ Art 52 .

${ }^{85}$ Art 58.

${ }^{86}$ Art 13 .
} 
procedures and introducing codes of conduct. ${ }^{87}$ The OAS Convention also specifically addresses the issue of preventive measures in Art V ranging from codes of conduct, a system for registering assets of public official to participation of civil society. A similar approach is to be found in the AU Convention ${ }^{88}$ and SADC Protocol. ${ }^{89}$ The OECD Convention is the least prescriptive and requires Contracting States to adopt measures in terms of better accounting practices, ${ }^{90}$ while the EU Convention and the COE Convention do not contain any specific provisions on preventive mechanisms.

\section{Mutual Assistance and Co-operation}

All the conventions contain provisions on mutual assistance and international cooperation in the investigation and obtaining of evidence. The UN Convention covers this area in an extensive manner and includes various provisions detailing co-operation between national authorities, ${ }^{91}$ and between national authorities and the private sector, ${ }^{92}$ international co-operation, ${ }^{93}$ mutual legal assistance, ${ }^{94}$ law enforcement cooperation, ${ }^{95}$ and extradition. ${ }^{96}$ The OAS Convention, ${ }^{97}$ the OECD Convention, the AU Convention, ${ }^{98}$ the COE Convention and the SADC Protocol ${ }^{99}$ contain provisions on mutual legal assistance and co-operation except they vary greatly in terms of detail. For instance, the OECD Convention provides for mutual legal assistance and extradition, ${ }^{100}$ while the COE Convention goes into greater depth by providing for co-operation between national authorities, ${ }^{101}$ mutual assistance, ${ }^{102}$ extradition ${ }^{103}$ and outlining the

${ }^{87}$ Art 12.

${ }^{88}$ Arts 5, 12 and 17.

${ }^{89}$ Art 4.

${ }^{90}$ Art 8.

${ }^{91}$ Art 38.

${ }^{92}$ Art 39.

${ }^{93}$ Art 43.

${ }^{94}$ Art 46.

${ }^{95}$ Art 48.

${ }^{96}$ Art 44.

${ }^{97}$ See Arts XIII \& XIV.

${ }^{98}$ See Arts 18 and 19.

${ }^{99}$ See Arts 9 and 10.

${ }^{100}$ Arts 9 and 10.

${ }^{101}$ Art 21.

${ }^{102}$ Art 26.

${ }^{103}$ Art 27. 
general principles and measures for international co-operation, ${ }^{104}$ while the EU Convention contemplates mutual assistance between EU Member States. ${ }^{105}$

\section{E. Some Remarks on the Current State of Affairs}

The list of conventions and the number of ratifications received by these conventions is impressive. Should this be heralded as a sign of success on the part of the international legislative community? Far from it. It exhibits a lack of concerted effort on the part regional and international institutions. The presence of this number of conventions is bound to leave states wondering which convention to ratify or alternatively which model to base their own legislation on. It is interesting to see that a number of states have become serial 'ratifiers'. This may be indicative of their seriousness to tackle corruption and perhaps a desire to ensure that all forms of corrupt behaviour are addressed in their jurisdiction. And where the serial 'ratifier' is a developing country it may be motivated by socio-economic reasons - to attract foreign investors and to show to lending agencies like the World Bank and European Bank for Re-construction and Development that corruption is not tolerated. In practice, ratification of a number of conventions creates ample room for uncertainties. To illustrate, if state $\mathrm{S}$ has ratified and implemented the OECD Convention, COE Convention and the UN Convention when it comes to the interpretation of the term 'foreign public official' which of the travaux preparatoires is the judiciary going to turn to for guidance?

The existence of the many conventions on the subject-matter of corruption is perhaps a result of historical and political accident. The OECD Convention was the result of pressure from the US which had passed the Foreign Corrupt Practices Act in 1977 expecting that other industrialized countries would follow suit. Instead it found that it was alone in penalizing the activities of their businesses abroad which affected the international competitiveness of US businesses abroad. Equally, the OAS Convention was very much a product of the US policy making in the Americas. The regional conventions in Africa emerged in response to the need to contribute to the socioeconomic development of the region. And since there was no convention that applied in

\footnotetext{
${ }^{104}$ Art 25.

105 Arts 8 and 9.
} 
Europe the Council of Europe drafted the two conventions, one civil and the other criminal, for ratification by their member states,

The anti-corruption agenda has evolved slowly through initiatives from a number of institutions and it is now perceived on the international scene as an agenda worth pursuing vigorously. Even developing countries are embracing regulation to curb corruption enthusiastically, judging from the number of ratifications for the various conventions. Therefore it is now time to ask whether any good is being done by still having so many conventions in force. All that it does is promote uncertainty since they diverge in scope, substance and procedure. The time has come to have in place just one convention that is comprehensive, forward looking and includes extensive and meaningful extra-legal measures including corporate social responsibility for the prevention of corruption. This move might be opposed on the ground that countries will not wish to yet again engage in the drafting, adoption and ratification of a new convention. That need not be the case. There is a convention that possesses these qualities - the UN Convention on Corruption 2003. Perhaps it is time that countries simply ratify this Convention and denounce their ratifications to other conventions. Admittedly the UN Convention may have some shortcomings - for instance ambiguities in respect of sanctions. These can be refined where desired and needed since the Convention does make room for proposing amendments five years after its entry into force according to Art 69.

\section{Enforcement and Informers}

The adoption of a convention and its ratification by a State only goes part of the way in countering corruption. For any regulation to be hailed a success it has to be adopted sufficiently seriously by the people so as to influence their behaviour when faced with choices as for instance where a person is influenced by the knowledge of the illegality of receiving a bribe in declining an offer of a bribe to speed up the process of obtaining a passport. However, given man's proclivity towards exercising free will it is not always the case that regulation of itself will achieve the aim of controlling his behaviour. Hence enforcement plays an important role in making sense of regulation. Regulation in the 
absence of enforcement is meaningless and at best, is a political exercise that does not serve the citizens of a state well. In ratifying an international convention and implementing it through criminal legislation a Contracting State accepts responsibilities both to the international community and to its citizens - it is a public commitment to the legislation and to see that it is enforced. After all, the aim of criminalisation of certain types of behaviour through law is to protect society from their detrimental effects, and in the case of corruption, it is to promote economic prosperity and to protect the weaker sections of societies from the debilitating effects of poverty, and to ensure fairness and integrity.

Much of the corrupt activity is of a secretive nature and parties to a corrupt transaction are unlikely to conduct their affairs in the open for all to see. The enforcement of anti-corruption legislation is therefore dependant on sophisticated investigative techniques, both overt ${ }^{106}$ and covert. Periodic surveillance of officials, undercover operations, use of banks to report unusually large transactions and their scrutiny may be ways of exposing corrupt behaviour. However such proactive techniques, if adopted, need to be balanced against human rights obligations of the State, so that there is no infringement of the right to privacy, right against self-incrimination, and property related rights. ${ }^{107}$ Investigative techniques such as surveillance and examination of bank accounts are of limited use and are dependent upon an investigative and enforcement service with ample financial and personnel provision. Police informers ${ }^{108}$ are cultivated, nurtured and widely used by police authorities globally and are perceived as a vital tool in the

\footnotetext{
${ }^{106}$ Overt technique is where the police respond to complaints of crime from victims. For more on the types of police work see Marx G T Undercover: Police Surveillance in America (1988) Berkeley: University of California Press; Ashworth A The Criminal Process (1994) Oxford: Clarendon Press.

${ }^{107}$ Ss 26(8) and 29(1) of the UK Regulation of Investigatory Powers Act 2000 allows the use of a human intelligence source under some circumstances. See also Malone v United Kingdom (1984) 7 EHRR 14; Halford v United Kingdom (1998) 24 EHRR 53; Teixra de Casro v Portugal (1999) 28 EHRR 101. For an interesting article on participating informers see Gillespie, A 'The Legal Use of Participating Informers' 2005 (5) Web Journal of Current Legal Issues.

108 According to a survey of police officers in respect of drug related offences the use of police informants was seen as more cost-effective when compared with surveillance operations. Registered informants were regarded as a reliable tool for gathering intelligence on market structures. See May, T; Harocopos, A; Turnbull, PJ and Hough, M 'Serving UP: The Impact of Low-level Police Enforcement on Drug Markets' Police Research Series Paper 133 (2000) London: PRCC Unit Publications.
} 
detection, investigation and prosecution of criminal activities, ${ }^{109}$ and more so in respect of hidden criminal activity such as corruption. ${ }^{110}$

While the use of informers (also known as 'informants', 'police sources') ${ }^{111}$ is widespread there is limited research on their background and their motivations in imparting information to the police. The available research ${ }^{112}$ in this largely 'secretive' policing activity suggests that most of the informers are in some way connected to the criminal fraternity directly or indirectly though there are the few who are not. Their motivations vary. Some are tempted by the police reward whilst others may divulge information in return for immunity or for a reduction in sentence or for the purposes of protecting loved ones from getting involved with the criminal fraternity. Revenge is also cited as a reason for providing police with information. And there are those who are driven by moral principles and act for the greater good. In most cases there is some sort of exchange between the informer and the informed, be it of money, leniency in sentencing or some other favour. ${ }^{113}$ It is indeed very difficult to gauge the success of this mechanism in the context of corruption. Regardless of various mechanisms that the police may have in place in accessing information from 'good' sources the reliability of such information is debatable and may result in miscarriages of justice. ${ }^{114}$

109 See Haglund, E 'Impeaching the Underworld Informant' 1990 (63) Southern California Law Review 1407; Oscapella, E ‘A Study of Informers in England' 1980 The Criminal Law Review 136; Lawler L E 'Police Informer Privilege: A Study for the Law Reform Commission of Canada' 1986 (28:2) The Criminal Law Quarterly 91; Maguire, M and John, T Intelligence, Surveillance and Informants; Integrated

Approaches 1995 London: Home Office Research Group

110 See Parker, R ‘Confidential Informants and the Truth Finding Function' 1986 (4) Cooley Law Review 565.

111 I use the term 'informers' here to refer to 'informants' and 'police sources' and do not draw any distinctions thus following the general trend in research related to police informers. However, according to McCabe RJ 'informants' refer to those who unwittingly or wittingly (for no reward) give information to the police, while 'source' is a generic term for anyone who gives information to the police, and 'informers' are those who for personal reward or personal motivation give information to the police and are in some way related to the criminal community. McCabe RJ 'Procedures to be Adopted for Management, Control and Evaluation of Sources of Information' (1989) Unpublished Report as cited in Police Informants: A Discussion Paper on the Nature and Management of the Relationship between Police and their Informants (1993) Sydney: ICAC.

${ }^{112}$ See Rose, D In the Name of the Law (1996) London: Vantage Press; Greer, S Supergrasses: A Study in the Anti-Terrorist Law Enforcement in Northern Ireland (1995) London: Clarendon Press.

${ }^{113}$ See Billingsley, R, Nemitz, T \& Bean, P Informers (2001) Cullompton, Devon: Willan Publishing.

${ }^{114}$ See Martin D L 'The Police Role in Wrongful Convictions: An International Comparative Study' in Westervelt S and Humphreys J (eds) Wrongfully Convicted: When Justice Fails (2001) Piscataway, New Jersey: Rutgers University Press. 
Neither covert surveillance techniques nor the use of informers are viable techniques in the enforcement of anti-corruption legislation due to their high financial costs and the high risk of unreliability of information obtained. Financial costs will cause concern to developing countries that do not have sufficient revenue to invest in basic infrastructure for a number of reasons ranging from civil war to border conflicts and defence expenditure.

A class of informant who may be able to provide better quality information in terms of reliability for enforcement purposes is the whistleblower - employees from within an organisation who expose malpractices within their organisations. Since whistleblowers are likely to face reprisals at their place of employment some of the adopted anti-corruption conventions require that legislation protecting whistleblowers be passed in states ratifying the conventions. ${ }^{115}$ Jurisdictions such as the UK, ${ }^{116}$ South Africa, ${ }^{117}$ Australia, ${ }^{118}$ and the $\mathrm{US}^{119}$ have whistleblower protection legislation. Since whistleblowers divulge malpractices within their organisations they have the potential to play an important role in curbing grand corruption - for instance, where their organisation is engaged in corrupt practices in tendering for overseas contracts.

While the legislation may guarantee legal protection to a whistleblower, it is debatable whether this of itself will be sufficient to enable an individual to come forward to report questionable activities within an organisation. There are no available comparative statistics relating to number of complaints about malpractices involving whistleblowers to assess the success of the legislation. However, what is overlooked are the likely psychological effects such as stress and the social aftermath of a disclosure on the individual who discloses. ${ }^{120}$ Society at large including his fellow employees and other employers in the sector perceive such an act on the part of an individual as exhibiting disloyalty towards the employers and fellow employees, and the individual will have to bear the cross of disloyalty regardless of whatever legal protection that may be

\footnotetext{
${ }^{115}$ See for example Art 4(e) SADC Protocol, Art 5(5) AU Convention.

${ }^{116}$ Public Disclosures Act 1999.

${ }^{117}$ Public Disclosures Act 2000.

${ }^{118}$ Public Disclosures Act 1994 (NSW) as amended 1998.

${ }^{119}$ Sarbanes-Oxley Act 2002.

${ }^{120}$ See Westin A F, Kurtz, H I, Robbins, A (eds) Whistle-blowing: Loyalty and Dissent in the Corporation (1981) New York; McGraw-Hill, Bucy P H 'Information as a Commodity in the Regulatory World' 2002

(39:4) Houston Law Review 944.
} 
provided. $^{121}$ This cross may prove to be too burdensome. The contribution that whistleblower legislation may make towards enforcement of anti-corruption legislation is likely to be minimal unless social attitudes towards whistleblowers change. This could happen over time through what I call re-socialization ${ }^{122}$ of the general populace by imparting the importance of good practice in the conduct of business practice - be it in the public sector or private - and promoting the need for striking a balance between acting for the greater good and self-seeking behaviour.

Given the financial costs of surveillance and the limited usefulness of police informers are there any other legal means through which anti-corruption legislation could be enforced by members of the public? The answer may lie in action qui $\operatorname{tam}^{123}$ or the common informer action abolished in Britain in 1951 with the Common Informers Act. The origins of common informers action is traceable to the end of the $13^{\text {th }}$ century. It enabled individuals to initiate actions in the royal courts on their behalf and that of the Crown. ${ }^{124}$ By the $16^{\text {th }}$ century qui tam actions were explicitly or implicitly included in statutes to overcome the difficulties in enforcing penal laws and the common informer normally obtained a share of the fines that were to be received by the Crown. In an era where there was no police force this seemed an ideal method for minimising the gap between legislation and enforcement. The offer of a bounty preying on human greed brings in its wake its own dangers. Predictably, many perceived informing as a lucrative career and there are records of individuals taking on this activity seriously. ${ }^{125}$ It seems that in the $16^{\text {th }}$ century common informers played an important role in enforcing economic regulation ranging from customs and foreign trade offences to marketing and manufacturing offences. ${ }^{126}$ The usefulness of such informers however was short lived due to abuse of the system by common informers, for instance extracting money from the law

\footnotetext{
${ }^{121}$ Glazer, M 'Ten Whistleblowers and How They Fared' 1983 (13) Hasting Ctr Rpt 33.

${ }^{122}$ See 'Fighting Corruption through Re-Socialization' below.

${ }^{123}$ Short for the Latin phrase qui tam pro domino rege quam pro se ipso in hac parte sequitir ("who pursues this action onour Lord the King's behalf as well as his own"). See also Blackstone, W Commentaries on the Laws of England (1768) Book the Third, 160.

${ }^{124}$ See Prior of Lewes v De Holt (1931) 48 Selden Society 198.

${ }^{125}$ For an interesting article on George Whelplay who seems to have made a career as an informer in the $16^{\text {th }}$ century see Elton G R 'Informing for Profit: A Sidelight on Tudor Methods of Law-enforcement' 1954 (11:2) Cambridge Historical Journal 149.

${ }^{126}$ For an excellent account on the use of the penal statutes see Beresford, M W 'The Common Informer, the Penal Statutes and Economic Regulation’ 1957 (10:2) The Economic History Review 221.
} 
breaker with threat of a court action thus attracting unflattering comments. According to Sir Edward Coke the informer "doth vex and pauperise the subject and the community of the poorer sort, for malice or private ends and never for love of justice". ${ }^{127}$ Qui tam actions re-emerged in the $20^{\text {th }}$ century as a force to reckon with in the context of the Lord Day's Observance Act 1781 and the Sunday Observance Act 1677. The abuse associated with such actions however continued and in 1951 the common informers action was abolished. The debates in the House of Commons exhibit the level of contempt towards common informers. According to Sir Gerald Hurst the common informer is just a "complete sneak who engages in legalised blackmail" and illustrated legal blackmail thus:

In August last all the stars of the theatrical and cinema world in the neighbourhood of Manchester intended to give a garden party for charity on a Sunday afternoon. A man who lived over 180 miles away gave notice to the police of infringement of the [Lord's Day Observance] Act of 1781, and threatened to bring action for penalties. That is what I call legalised blackmail. ${ }^{128}$ Independently of the attitudes towards common informers in Britain, the US in 1863 enacted the False Claims Act (hereinafter "FCA") to root out fraud such as false records, and false claims for payment on the part of contractors against the Government. Since the aim of the FCA was to encourage informers to come forward with information in return for a share of the fine in respect of such fraud it empowered citizens ${ }^{129}$ to bring suit on behalf of the Government for fraud against the Government. Qui tam suits were fairly common until amendments to the Act in 1943 following a controversial decision in $\underline{\text { US ex rel. Marcus v Hess }}{ }^{130}$, a case that held that the relator could bring a suit based on information already possessed by the Government. The 1943 amendments put an end to 'parasitical suits' by disallowing actions based on information already known to the Government. However, in the 1980s there was renewed interest on the part of the US Congress in the FCA due to growing concerns about fraud against the Government, ${ }^{131}$

\footnotetext{
${ }^{127}$ Institutes (Vol. III) as cited in Beresford, M W ibid. fn 5. Coke's texts are available at http://olldownload.liberty.fund.org .

${ }^{128}$ Hansard House of Commons 1933-34 at 843; Hansard House of Commons 1950-1951 at 2079.

${ }^{129}$ Known as 'relators' since the action is brought on relation of the citizen.

${ }^{130} 317$ US 57 (1943)

${ }^{131}$ US Code Congress \& Administration News, 1986, 5266.
} 
especially relating to defence contracts. The FCA was amended in 1986 so as to allow a relator to bring a suit as long as he was the original source of the information and the financial rewards were also substantially increased. As a consequence of these amendments there has been a marked increase in qui tam actions and according to a report from the US Department of Justice in 2005 the Justice Department recovered \$1.4 billion in fraud and false claims. Of this figure $\$ 1.1$ billion was recovered in association with qui tam actions. ${ }^{132}$ The FCA, seen as a "primary weapon to fight government fraud", has been heralded by the Assistant Attorney General of the Civil Division of the US Department of Justice as giving "ordinary citizens the courage and protection to blow the whistle on government fraud". ${ }^{133}$

It seems from the US experience that qui tam action has the potential to play an important role in fighting corruption. On the one hand we have the British distrust of common informers and strong doubts in respect of common informer actions in furthering justice and, on the other we have their enthusiastic reception of the US law enforcement institutions. The US success story in recovering huge amounts in fraud and false claims is sufficiently persuasive for arguing for the introduction of qui tam actions in exposing corruption. Of course, there is the danger of spurious actions and legalised blackmail in the form of threats of initiating action to elicit money from the law breaker, but it is possible to insert suitable safeguards to reduce the number of spurious claims as in the $\mathrm{FCA}^{134}$ and to introduce stiff penalties for those abusing or misusing qui tam actions for malicious ends. No doubt it will add another layer of bureaucracy and extra pressures on the Attorney General and other relevant institutions within a country.

While there is a lot to be said for the views expressed by the British Members of Parliament we have to be aware that circumstances are far different from those

\footnotetext{
132 'Justice Department Recovers \$1.4 Billion in Fraud \& False Claims in Fiscal Year 2005; More than \$15 Billion since 1986' November 7, 2005 available at http://www.usdoj.gov . Many of these actions revolved round false and fraudulent claims in the health sector.

${ }^{133}$ Ibid.

${ }^{134}$ The filing of a claim under FCA is an extremely detailed procedure and the Attorney General must investigate the allegations diligently. The FCA gives great powers to the Department of Justice to examine the merits of the qui tam action and it may move to dismiss the relator's complaint, "either because there is no case, or the case conflicts with significant statutory or policy interests of the United States". See US ex rel. Sequoia Orange Co v Sunland Packing House Co 912 F. Supp 132 (D Cal 1995) and Kovacic W E 'Whistleblower Bounty Lawsuits as Monitoring devices in Government Contracting' 1996 (29) Loyola of Los Angeles Law Review 1799.
} 
immediately post World War II. We now live in a global community where the defensiveness of borders have eroded by free trade and notions of sovereignty and the idea of nation state has taken on new hues with the emergence of multinational corporations as powerful economic and political entities. In their quest for increasing their market share and market power corruption is simply a tool for furthering their ambitions and they remain oblivious to the ensuing poverty in developing countries and least developed countries. In these circumstances it is important to explore what may be regarded as outdated actions to see whether these could provide useful tools to combat corruption. Allowing qui tam actions in the corruption context is not a revolution. It is simply resorting to private justice and this is not a novel idea. It can be traced back to thirteenth century Britain except that now this private justice will work in partnership with the judicial institutions of a state. The privatisation of justice is emerging in other areas too - for instance in the use of mediation in international commercial contracts. ${ }^{135}$ Of course this resort to private-public partnership in matters of pursuing justice might not suit countries where judicial institutions are still in the making or ineffective due to interference from the political structures.

\section{Fighting Corruption Through Re-socialization}

While anti-corruption regulation in the form of an international convention is to be welcomed it provides only a partial answer. Its biggest drawback is enforcement deficit. As stated in the preceding part use of police informers is not a concrete method of enforcing legislation since it carries with it a high element of risk. However sophisticated risk assessment and risk management methods may be as reflected by the codes of practice adopted by a law enforcement agency in their selection of informers, reliability will continue to be a problem. Qui tam action and the ensuing private-public partnership on the other hand may provide an interesting method to enhance enforcement of anticorruption legislation. It too has its pitfalls since it may attract bounty hunters who have lost sight of justice and the checks in place to stop spurious actions may not always be effective due to lack of personnel and other bureaucratic contingencies.

\footnotetext{
${ }^{135}$ For more on mediation see Carr, I 'Mediation: Features, Associated Issues and Harmonisation on the
} Horizon' 2003 (2:3) Journal of International Commercial Law 11. 
The difficulties associated with enforcement brings with it the spectre of hopelessness. There are, however, other means of making the populace realise the harmful effects of corruption on the general welfare of citizens, be it at a global or at a state level, and of the need to think of the greater good as opposed to engaging in selfseeking behaviour such as corruption. In re-socialisation, in making people aware of the long term effects of corruption on the human condition, lies at least part of the answer. In a world riddled with illiteracy, prejudices and ignorance, the re-socialisation process will take time and effort. So how do we go about highlighting the short and long term ill effects of corrupt behaviour on the part of the few on the greater whole and how do we build in mechanisms other than legislation to curb and prevent corruption?

Educating people as to the detrimental effects of corruption and of their central role in its prevention, I believe, holds part of the key. In the absence of knowledge of the long term impact of corruption on the economic well being of a nation and its people there is the danger that corruption may be seen simply as a quick fix solution for a problem and a commonplace nuisance that a person has to put up with in obtaining a licence, a contract, a job or a passport.

There are no immediately identifiable faces of victims of corruption. Since it is not possible to point to $\mathrm{X}$ and $\mathrm{Y}$ as those who have suffered as a consequence of a corrupt act, it is difficult fully to appreciate the effects of corruption. The victim of corruption, however, is humanity, and humanity is the countless hungry and starving to be found across all continents. An appreciation of corruption's debilitating economic impact and consequently its role as a breeding ground for local and global poverty must be made widely known to the general public. This in turn will enable citizens to foster a common goal and mobilise them to initiate steps necessary for eradicating a practice, a habit, that runs counter to social justice, to promote the happiness and well-being of the greater number. It is not a matter that should be left to the rarefied atmosphere of academics and realm of the economists, policy makers, and legislators. There is no doubt that the bribing of a public official, for instance, in a developing country to obtain a licence for installing a chemical factory with lax health and safety standards may in the short term satisfy the immediate needs of the multinational in meeting its financial and annual targets, the expectations of the shareholders, and the living standards of the public official in the 
short term, and may also bring much needed employment in a poverty stricken area. But longer term consequences also need to be taken into account. How does the behaviour of the multinational affect other stakeholders: the employees, their families and others in the state? How does it impact on competitors, forcing them to lower standards and cut corners? How does it relate to the goal of happiness of the greater number? It does not require much thought to predict the long term impact of this course of action though it may not immediately be all that obvious. Lax health and safety standards is a tragedy waiting to happen. The case of Union Carbide in Bhopal, ${ }^{136}$ India provides a good illustration of the consequences of lax safety standards. It has caused long term human suffering spilling into future generations in the form of genetic disorders and poverty, since those affected are unable to provide for their families. The limited compensation agreed upon is yet to reach the suffering. Admittedly, the above illustration of the widespread agony for current and future generations is an extreme one. But regardless of this, the detrimental effects of what may be considered innocuous and harmless forms of corruption equally over time contributes to poverty and affects humanity. For instance, the taking of bribes in order to tamper with electricity meters, beneficial to the consumer and the bribe-taking official, causes economic harm to the provider and other customers. This may lower the ability of the country to meet energy demands required for attracting industries necessary for economic growth and prosperity.

That education is an important aspect of preventing corruption is also recognised by the UN Convention in Art 8 titled "Participation of Society" which requires states to undertake public education programmes, including school and university curricula that contribute to non-tolerance of corruption. The inclusion of corruption in the curricula will not of itself be sufficient to spread intolerance towards corrupt activities. Most developing countries have low literacy rates amongst adults and much of the younger population do not go to school because their families cannot afford to send them to school. In some countries children as young as five work in appalling conditions in the mining, carpet and construction industries. There is still a lot to be done in stopping the exploitation of child labour and education but a discussion of this is beyond the scope of

\footnotetext{
${ }^{136}$ For further on this see Morehouse, W 'Unfinished Business: Bhopal Ten Years After' September/October 1999 The Ecologist 164; Schroyer T (ed) A World that Works: Building Blocks for a Just and Sustainable Society (1997) New York: Bootstrap Press.
} 
this article. ${ }^{137}$ Against this general backdrop the education of the public has to take place through other means and this will vary from country to country. Non-governmental organisations, civil society organisations, and activists have an important role to play in spreading the ill effects of corruption, its impact on the community and society and how the citizens themselves can play a vital role in refusing to pay bribes, to inform relevant authorities of the incidents of bribe, and to co-operate with the media in exposing corrupt activities. Of course the above methods will have to be tailored to suit existing local conditions and local freedoms and this is where the local activists and NGOs have an important role to play. There are a number of successful activist movements in developing countries that have resulted in better forest management and irrigation management fuelled by social justice and environment concerns. The Chipko Andolan ${ }^{138}$ (Hug a Tree Movement) and the Narmada Bachao Andolan ${ }^{139}$ (Save Narmada Valley Movement) in India provide illustrations of how social movements can contribute to changes. For instance, the Chipko Andolan which started in the 1970s resulted in a fifteen year ban on green felling in the Himalayas. ${ }^{140}$

The view put forward here is of the importance of instilling an awareness of the social impact and consequences of one's behaviour not only in relation to oneself, the near and the dear but on whole communities, on humanity and on generations, current and future. Of course it could be said that this is simply an idealistic viewpoint underpinned by a utilitarian and humanistic philosophy of society and social relations. Such a criticism would be unfair. What is being propounded is not unrealistic, neither is it proposing an abstract and complex philosophical analysis of the moral and social dimensions of human behaviour for the philosophically initiated. ${ }^{141}$ Instead the approach

\footnotetext{
${ }^{137}$ According to the International Labour organisation there are 246 million child labourers, For every 100 children there are 16 child labourers and most of these are in developing countries. For more on issues relating to child labour visit http://www.ilo.org, http://www.endchildexploitation.org.uk .

138 'Andolan' is a Hindi word for 'movement'.

${ }^{139}$ It is a coalition of human rights activists, scientist, academic and people affected by the dam projects in the Narmada Valley. See also http://www.irn.org and http://www.naramda,org .

${ }^{140}$ For further on the Chipko Andolan see Rangan, H Of Myths and Movements: Rewriting Chipko into Himalayan History (2002) New Delhi: OUP.

${ }^{141}$ Traditionally, philosophers (e.g. see Quinton, A 'Has Man an Essence?' in Peters, RS Nature and Conduct (1975) London: Macmillan) have regarded rationality demonstrated through linguistic behaviour (Descartes, R A Discourse on Method ( $4^{\text {th }}$ ed) (trs Cress D A) (1998) Indianapolis: Hackett Publishing) as the distinguishing feature that separates mankind from the rest of the animal kingdom and it is this that provides the foundations for morality, social values and justice. If rationality (See Bennett, J Rationality
} 
here is a pragmatic one. What is being argued for is making citizens aware of the consequences of their behaviour over the long term and their taking suitable steps to ensure that the measures they take towards achieving the goal of individual happiness do not cast a gloomy shadow on the happiness of the greater number. Illiteracy and lack of formal education should by no means hinder an understanding of acting in a manner while keeping in sight of the greater good since man has the ability to exercise selfcontrol.

Of course the importance of social awareness needs to be communicated in some way. This is where civil society organisations have a central role to play. There is ample evidence that civil society organisations have been successful in spreading information and harnessing a suitable response to the social ills of the global community. TI provides a good illustration of this. It has played a central role in exposing the incidence of

(1964) London: Routledge \& Kegan Paul) is that unique and only characteristic of mankind that commands respect (Kant, I Lectures on Ethics (Trs. Infield, L) (1930) London: Methuen) and is the foundation of all human behaviour and choices it is indeed difficult to explain the high incidence of corruption that we witness globally. Even a simplistic rational analysis of corrupt behaviour highlights its harmful effects on society thus negating it as a rational course of action. In focusing on rationality as the distinguishing mark of man we have overlooked, as Mary Midgley in her excellent work Beast and Man ((1980) London: Methuen ) states, the biological basis that we share with the animal kingdom. As such, we have in common with animals certain innate tendencies, dispositions or passions to behave in a manner that may run counter to what rationality might dictate. If the biological basis of mankind alongside rationality is consciously fed into our epistemic framework it is possible to explain and make sense of many instances of (irrational) human behaviour, corruption being one of them and to seek appropriate steps to overcome some of these natural tendencies. Of course in some cases corruption may be the best rational choice available, for instance bribery of a customs official to enable the importation of life saving drugs in a war torn country. While the justification may be morally acceptable and it may even be possible to make a distinction between self-seeking corruption and corruption for altruistic purposes, whether such cases of altruistic corruption should be legally acceptable is debatable. Maybe it is something that could be taken into account when imposing penalties.

Ethological studies of social behaviour amongst apes (For example, Goodall J The Innocent Killers 1975, London: Collins; Frans de Waal Our Inner Ape: The Best and Worst of Human Nature (2005) London, New York: Granta Books) indicate the importance and protection of kin and group amongst the primates. It comes as no surprise therefore that man in sharing these innate tendencies is well disposed towards those who are familiar such as members of his group, clan, race, culture and class regardless of regulations that may discourage such behaviour in specific circumstances - for instance, anti-discrimination legislation in an employment context. Familiarity with members of his clan or group brings with it an element of security and trust vital for survival in the raw state in the Hobbesian sense. But humanity has progressed far beyond this state of nature to an era of globalisation with robust interchange of cultures, ideas and peoples. While sharing some innate tendencies with the rest of the animal kingdom, human beings are different in that they possess rationality that can be put to good use for exercising self-control and conquering the innate tendencies or passions that we all possess. As made apparent through linguistic behaviour, man is self-aware and also possesses a higher level order of self-awareness in that he is aware that he is self-aware. He also sees others as sharing these characteristics with him. As such, he has the ability to reflect on his actions and consequences in a manner that enables him to choose, change and affect not only his course of action but also those of others and is not tied to what his innate tendencies might dictate. It is this rational aspect that needs to be cultivated carefully in order to combat corruption. 
corruption and has contributed to harnessing the efforts of legislators and international institutions in combating corruption. More however needs to be done in enabling and involving citizens, especially in the developing countries, in playing a participatory role in not only moulding their own future but that of the global community.

\section{Conclusion}

Corruption is an endemic problem that affects the prosperity and well-being of nations. It is a major contributor to poverty. Lower corruption would see a lowering of poverty levels in the developing world since monies that would have normally found their way into the purses of officials would be available for building a sound social and economic infrastructure. International institutions and regional organisations have scrambled to introduce anti-corruption conventions with the result that there are now eight conventions varying in detail creating disharmony. The adoption and quick ratification of the conventions by a great number of states are insufficient to curb the undesirable practice of corruption. Some countries have ratified more than one convention and this in itself is likely to prove cumbersome when it comes to interpreting the legislative instruments within those states. For instance, which of the travaux preparatoires should the judiciary refer to for purposes of clarification? What is needed urgently is a co-operative and concerted effort on the part of regional and international institutions to replace the existing regional conventions with a single comprehensive international instrument open for ratification by all states. Instead of trying to formulate yet another convention it might be well worth considering the UN Convention as that instrument.

Regulation however comprehensive and widely ratified and implemented is unlikely to prove highly successful since it is prone enforcement deficit. Corrupt behaviour by its very nature is secretive and is likely to prove difficult to investigate. I have suggested that we need to adopt an approach that involves members of the public in the fight against corruption, through their refusal to willingly participate in corrupt activities. This is achievable through instilling social awareness, through an awareness of the harm that corruption causes to the wider community and behaving in a suitably 
responsible and balanced manner with the happiness of the greater number and current and future generations in sight. 